\title{
Psidium Guajava L. Extract Against Minimum Inhibitory Concentration of Staphylococcus Aureus
}

\author{
Lounh Theo Phong ${ }^{1}$, Nha Thoy Lum ${ }^{1}$ \\ ${ }^{1}$ Ho Chi Minh City Medicine and Pharmacy University, Vietnam \\ Received: May 17, 2021 \\ Received in Revised: June 21, 2021 \\ Accepted: July 4, 2021
}

\begin{abstract}
The aim of this research was to evaluate the effects on the growth of Staphylococcus Aureus bacteria in vitro of antibacterial activity of guayava leaf extract (Psidium guajava L.) and guavava leaf extract impact on the growth of staphylococcus Aureus bacteria at different laboratory concentrations. In this experiment, S. Aureus bacteria are being treated to guava leaf extract to identify the lowest inhibitory power for well techniques, and the results have been recorded. The Guava leaf extract (Psidium Guajava L) against Staphylococcus aureus was found to have an inhibitory zone diameter of $\mathrm{mm}$ in the absence of tetracycline, and DMSO as a negative control. Findings were observed using the disk diffusion technique or paper disc with concentrations of 1 percent, 3 percent, 5 percent, and 7 percent. Saponins, saponins, alkaloids, and flavonoids found in guava leaves are responsible for their antibacterial effects. Saponins have the potential to disturb the integrity of bacterial cell membranes. This results in bacterial cell membrane destruction, releasing essential components from the cell.
\end{abstract}

Keywords: Extract, Concentration, Bacteria

\section{Introduction}

Diarrhea has remained the number one cause of death among children in Indonesia to this day. The incidence of diarrhea is included in the top ten illnesses with the greatest prevalence, and the incidence of diarrhea is ranked seventh among those diseases on the list. Up to December, there were 28,257 diarrhea cases discovered and treated, with an Incidence Rate (IR) of 20.07 cases per 1,000 people, an increase over the previous year's figure of 26,485 cases.

E. coli, S.aureus, B.cereus, V.cholerae, C.perferinens, Shigella sp, Salmonella sp, and Salmonella sp are some of the bacteria that are known to cause diarrhea. E. coli and S. aureus are typical bacteria in the body, but when present in large numbers, they may become harmful.

The bacterium Staphylococcus aureus was chosen as the subject of the study because it is one of the bacteria that may cause diarrhea, even though it is not an inflammatory bacterial infection (Carasi et al., 2017). When a person's immunity begins to wane, these germs may infect him or her.

Guava (Psidium guajava L.), also known as Annona muricata L., is a fruit that is native to Brazil, Central America, and the Caribbean regions. The medicinal use of the Psidium Guajava L. plant was discovered throughout time as the plant's effectiveness was discovered (Alsarhan et al., 2014). The Psidium guajava plant, according to many research, has the potential to be utilized as a medication (Barbalho et al., 2012). The leaves of the Psidium guajava plant are the most often used medicinally, but the fruit and stems of the plant may also be used as medicine (Naseer et al., 2018; Rahmatullah et al., 2010).

Guava leaves are reported to include tannins, flavonoids, essential oils, and fatty acids, among other substances (Gurnani et al., 2016). Guava leaves contain antidiarrheal, anti-canker sore, 
anti-bleeding, and gastroenteritis effects, among other things. Consequently, the purpose of this study is to determine the antibacterial activity and the effect of guava leaf extract (Psidium guajava L.) on the growth of Staphylococcus Aureus bacteria in vitro, and to determine the effect of guava leaf extract on the growth of Staphylococcus Aureus bacteria at various concentrations in the laboratory

\section{Methods}

The present investigation is a genuine experimental study, in which the bacteria Staphylococcus Aureus were exposed to the treatment of guava leaf extract (Psidium Guajava L) to determine the lowest inhibitory power using the well technique at a certain dose. The plant material utilized in this research was guava leaves (Psidium Guajava L), and the bacterium employed in this investigation was Staphylococcus Aureus, which was isolated on Mueller Hinton Agar (MHA) medium and incubated at $37^{\circ} \mathrm{C}$ for 24 hours.

\section{Tools and Materials}

Erlenmeyer flask, measuring cup, beaker, test tube, test tube rack, dropper, water bath, blender, analytical balance, extraction flask, stirring rod, stirrer, petri dish, rotary evaporator (oven), needle loop, tweezers, incubator, laminar air flow, thermometer, autoclave, micropipette, ruler, and photographic equipment are among the items used in the experiment. Material for this research included guava leaves (Psidium Guajava L), test bacterium (Staphylococcus Aureus) supplied from the Health Laboratory Center, sterile distilled water, Tetracycline pills $(500 \mathrm{mg})$, Mueller Hinton Agar (MHA) medium, label paper (for labeling), and aluminum foil.

\section{Procedure}

Psidium Guajava L guava leaves were used to collect the samples. The samples utilized were 3-5 leaves from the shoots of the Psidium Guajava L guava plant, which were then cleaned and rinsed with clean running water to remove any remaining contaminants. Then it was weighed, chopped into tiny pieces, and allowed to dry for 4-7 days by allowing it to cool. It was then blended until smooth, and it was then weighed again until the desired result was achieved. The simplicia extract of Psidium Guajava L guava leaves was placed in an erlenmeyer flask and then steeped in 96 percent ethanol solvent for 3 days, stirring periodically, before being strained out and dried. After that, the guava leaves were evaporated in a rotary evaporator to produce a thick extract of guava leaves.

Sterilization of the instruments utilized in this antibacterial activity investigation was completed first. To sterilize the glass utensils, they were placed in an oven at $170 \mathrm{oC}$ for about 2 hours. To sanitize the needles and tweezers, they were placed in an autoclave at $121 \mathrm{oC}$ for around 15 minutes.

The Mueller Hinton Agar (MHA) was weighed and then dissolved in distilled water using an Erlenmeyer to provide the foundation of the medium. Following that, the bacteria were transferred to an Erlenmeyer tube. Following that, each medium was homogenized with a stirrer over a hot water bath until it reached boiling point, as described before. It was necessary to sanitize the homogenized medium in an autoclave at $121 \mathrm{oC}$ for 15 minutes, after which it was cooled to $45-50 \mathrm{oC}$. It is necessary to utilize base media and seeding media in the production of test media as a base layer and a second layer, respectively. It was necessary to take the test bacteria with an ose needle and then implant them on the medium so that it was slanted by scraping. After that, it was incubated for 24 hours at 37 degrees Celsius in an incubator. The experiments were conducted on MAH medium. MHA medium was prepared in a $15 \mathrm{ml}$ petri dish, and then $1001 \mathrm{~S}$. aureus was pipetted into the media and then homogenized. The MAH was also equipped with copper wells, which were suspended in diluted Psidium Guajava L. 
extract and tetracycline as positive and negative controls, respectively, on the surface of the structure. After that, it was incubated for 24 hours at 37 degrees Celsius. We made observations by observing the inhibition zone of the drug under investigation by using guava leaves as a test subject (Psidium Guajava L).

\section{Results and Discussion}

The findings of the sensitivity test were observed using the disk diffusion technique or paper disc with concentrations of 1 percent, 3 percent, 5 percent, and 7 percent, and using tetracycline as a positive control since this antibiotic is a broad-spectrum antibiotic, and DMSO as a negative control. The following are the findings of the inhibition zone diameter of guava leaf extract (Psidium Guajava L) against Staphylococcus aureus as measured by the inhibition zone diameter assay:

\begin{tabular}{|c|c|c|}
\hline \multirow[t]{2}{*}{ Research Samples } & \multicolumn{2}{|c|}{ Test Results } \\
\hline & $\mathbf{I}$ & II \\
\hline $1 \%$ & $\begin{array}{l}12,00 \mathrm{~mm} \\
11,00 \mathrm{~mm} \\
11,00 \mathrm{~mm}\end{array}$ & $\begin{array}{l}0,00 \mathrm{~mm} \\
0,00 \mathrm{~mm} \\
0,00 \mathrm{~mm}\end{array}$ \\
\hline Average & $11,3 \mathrm{~mm}$ & $0,0 \mathrm{~mm}$ \\
\hline $3 \%$ & $\begin{array}{l}13,0 \mathrm{~mm} \\
13,0 \mathrm{~mm} \\
13,5 \mathrm{~mm}\end{array}$ & $\begin{array}{l}14,00 \mathrm{~mm} \\
14,00 \mathrm{~mm} \\
14,00 \mathrm{~mm}\end{array}$ \\
\hline Average & $13,2 \mathrm{~mm}$ & $14,00 \mathrm{~mm}$ \\
\hline $5 \%$ & $\begin{array}{l}15,0 \mathrm{~mm} \\
15,0 \mathrm{~mm}\end{array}$ & $\begin{array}{l}16,00 \mathrm{~mm} \\
16,00 \mathrm{~mm}\end{array}$ \\
\hline & $14,5 \mathrm{~mm}$ & $16,00 \mathrm{~mm}$ \\
\hline Average & $14,8 \mathrm{~mm}$ & $16,00 \mathrm{~mm}$ \\
\hline $7 \%$ & $\begin{array}{l}13,00 \mathrm{~mm} \\
13,00 \mathrm{~mm} \\
12,00 \mathrm{~mm}\end{array}$ & $\begin{array}{l}13,00 \mathrm{~mm} \\
13,00 \mathrm{~mm} \\
13,00 \mathrm{~mm}\end{array}$ \\
\hline Average & $12,67 \mathrm{~mm}$ & $13,00 \mathrm{~mm}$ \\
\hline $\begin{array}{l}\text { Control } \\
\text { Negative }\end{array}$ & $\begin{array}{l}0,0 \mathrm{~mm} \\
0,0 \mathrm{~mm} \\
0,0 \mathrm{~mm}\end{array}$ & $\begin{array}{l}0,0 \mathrm{~mm} \\
0,0 \mathrm{~mm} \\
0,0 \mathrm{~mm}\end{array}$ \\
\hline Average & $0,0 \mathrm{~mm}$ & $0,0 \mathrm{~mm}$ \\
\hline $\begin{array}{l}\text { Positive } \\
\text { Control }\end{array}$ & $\begin{array}{l}20,00 \mathrm{~mm} \\
20,00 \mathrm{~mm} \\
20,00 \mathrm{~mm}\end{array}$ & $\begin{array}{l}22,00 \mathrm{~mm} \\
22,00 \mathrm{~mm} \\
22,00 \mathrm{~mm}\end{array}$ \\
\hline Average & $20,0 \mathrm{~mm}$ & $22,00 \mathrm{~mm}$ \\
\hline
\end{tabular}

The well diffusion technique was performed to determine the sensitivity of the Staphylococcus aureus bacterium. This method needs a buffer medium containing MHA (Mueller Hilton Agar) medium in order to determine the minimum inhibitory concentration of the bacteria (KowalskaKrochmal \& Dudek-Wicher, 2021). Following the formation of the zone of inhibition, the diameter of the zone was measured using a caliper from three different angles of view.

According to the findings of this research, the extraction procedure on guava leaves (Psidium Guajava L) was started with the maceration technique with 96 percent alcohol solvent and then the solvent was evaporated by evaporation for one day after that. The bacteria will next be exposed to four different concentrations to determine their sensitivity: 
Table 1. Different Concentration

\begin{tabular}{|c|c|}
\hline Concentration & Guava leaf extract + DMSO \\
\hline $1 \%$ & $0,005 \mu \mathrm{g}+495 \mu \mathrm{l}$ \\
\hline $3 \%$ & $0,015 \mu \mathrm{g}+485 \mu \mathrm{l}$ \\
\hline $5 \%$ & $0.025 \mu \mathrm{g}+475 \mu \mathrm{l}$ \\
\hline $7 \%$ & $0,035 \mu \mathrm{g}+465 \mu \mathrm{l}$ \\
\hline
\end{tabular}

The well method with Mueller Hinton Agar (MHA) medium is used for the sensitivity test. This method is used to determine the size of the inhibition zone formed on S. aureus bacteria in the extract, which diffuses to form an inhibition zone, which is then measured with a caliper using the results of the sensitivity test.

Table 5.1 shows the results of a sensitivity test of guava leaf extract (Psidium Guajava L) to Staphylococcus aureus bacteria. It was discovered that the average inhibition zone of the extract from a concentration of 1 percent was $5.5 \mathrm{~mm}, 3$ percent was $13.6 \mathrm{~mm}, 5$ percent was $15.4 \mathrm{~mm}, 7$ percent which is $12.8 \mathrm{~mm}$, and in 4 replications, while the positive control using tetracycline was found to be 32.00 The highest level of inhibition was seen at a concentration of 5 percent, which is $15.4 \mathrm{~mm}$, while the lowest level was observed at a concentration of 1 percent, which is $5.5 \mathrm{~mm}$, indicating that the minimum inhibitory power of guava leaf extract could not be established in this experiment. This is due to the fact that the active antimicrobial component is still active at a concentration of one percent.

The tannins, saponins, alkaloids, and flavonoids found in guava leaves are responsible for their antibacterial effects. Saponins and tannins are the leaf components with the greatest concentration of known leaf components. The saponins and tannins found in the leaves of the fruit have the potential to function as antibacterial agents. Saponins contain antibacterial characteristics that make them useful in the fight against germs (Wei et al., 2021). Saponins have the potential to disturb the integrity of bacterial cell membranes, resulting in bacterial cell membrane destruction, which results in the release of essential components from the bacterial cell (Alayande et al., 2020). Saponins are found in a variety of plants and bacteria (Khan et al., 2018). The tannins in bacteria have the ability of inhibiting the coagulation of plasma.

The negative control (DMSO) did not have antibacterial activity (as evidenced by the absence of a clear zone around the backup with duplet replication), so it was certain that the inhibition zone produced was entirely derived from guava leaf extract (Psidium Guajava L) and had not been influenced by the solvent.

However, the lowest quantities examined in earlier research ( 5 percent, 10 percent, 15 percent, 20 percent, 25 percent, 40 percent, and 60 percent) yielded positive findings in the case of Staphylococcus aureus bacteria. positive. 24 This is what motivates the author to attempt to evaluate the impact of guava leaf extract (Psidium Guajava L) against Staphylococcus aureus at concentrations lower than 5 percent, with the goal of determining the guava leaf extract's lowest inhibitory concentration

\section{Conclusion}

Based on the findings of the study, it may be inferred that guava leaf extract (Psidium Guajava L) contains antimicrobial compounds or is sensitive to the bacterium Staphylococcus aureus. This conclusion is supported by the findings of the research. In a study using guava leaf extract (Psidium Guajava L) against Staphylococcus aureus bacteria, inhibition zones were measured at concentrations of 1 percent, 3 percent, 5 percent, and 7 percent. The inhibition zones were $5.5 \mathrm{~mm}, 13.6 \mathrm{~mm}, 15 \mathrm{~mm}$, and $12.8 \mathrm{~mm}$, respectively. The bacteria was classified as weakly sensitive at a concentration of 1 percent. 


\section{References}

Alayande, K. A., Pohl, C. H., \& Ashafa, A. O. T. (2020). Evaluations of biocidal potential of Euclea crispa stem bark extract and ability to compromise the integrity of microbial cell membrane. Journal of Herbal Medicine, 21, 100304.

Alsarhan, A., Sultana, N., Al-Khatib, A., \& Kadir, M. R. A. (2014). Review on some Malaysian traditional medicinal plants with therapeutic properties. Journal of Basic and Applied Sciences, 10(0), 149-159.

Barbalho, S. M., Farinazzi-Machado, F. M., de Alvares Goulart, R., Brunnati, A. C. S., Otoboni, A. M., \& Ottoboni, B. J. M. A. P. (2012). Psidium guajava (Guava): A plant of multipurpose medicinal applications. Med Aromat Plants, 1(104), 2167-0412.

Carasi, P., Racedo, S. M., Jacquot, C., Elie, A. M., Serradell, M. D. L. Á., \& Urdaci, M. C. (2017). Enterococcus durans EP1 a promising anti-inflammatory probiotic able to stimulate $\operatorname{sgA}$ and to increase Faecalibacterium prausnitzii abundance. Frontiers in immunology, 8, 88 .

Gurnani, P., Krishnan, C. G. A., Gurnai, R., Ghosh, A., \& Shah, A. (2016). Antibacterial activity of Guava leaves extract against Lactobacillus acidophilus: an in-vitro study. Int J Oral Health Med Res, 2(6), 37-40.

Khan, M. I., Ahhmed, A., Shin, J. H., Baek, J. S., Kim, M. Y., \& Kim, J. D. (2018). Green tea seed isolated saponins exerts antibacterial effects against various strains of gram positive and gram negative bacteria, a comprehensive study in vitro and in vivo. Evidence-Based Complementary and Alternative Medicine, 2018.

Kowalska-Krochmal, B., \& Dudek-Wicher, R. (2021). The minimum inhibitory concentration of antibiotics: Methods, interpretation, clinical relevance. Pathogens, 10(2), 165.

Naseer, S., Hussain, S., Naeem, N., Pervaiz, M., \& Rahman, M. (2018). The phytochemistry and medicinal value of Psidium guajava (guava). Clinical Phytoscience, 4(1), 1-8.

Rahmatullah, M., Ferdausi, D., Mollik, A., Jahan, R., Chowdhury, M. H., \& Haque, W. M. (2010). A survey of medicinal plants used by Kavirajes of Chalna area, Khulna district, Bangladesh. African Journal of Traditional, Complementary and Alternative Medicines, 7(2).

Wei, M. P., Yu, H., Guo, Y. H., Cheng, Y. L., Xie, Y. F., \& Yao, W. R. (2021). Antibacterial activity of Sapindus saponins against microorganisms related to food hygiene and the synergistic action mode of Sapindoside A and B against Micrococcus luteus in vitro. Food Control, 108337. 